\title{
紫外光下高度稳定的无机钙钛矿/有机叠层太阳电池
}

刘忠范

北京大学化学与分子工程学院, 北京 100871

\section{Inorganic Perovskite/Organic Tandem Solar Cells with High Stability under UV Light}

\section{LIU Zhongfan}

College of Chemistry and Molecular Engineering, Peking University, Beijing 100871, P. R. China.

Email: zfliu@pku.edu.cn
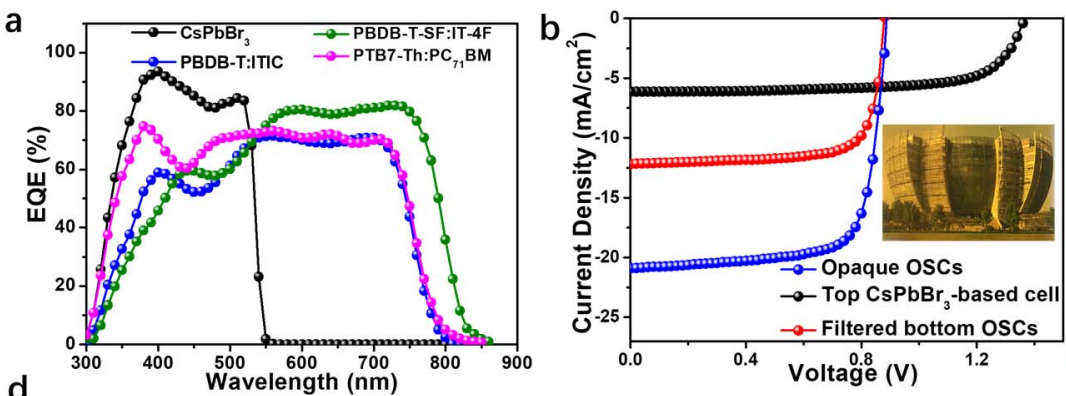

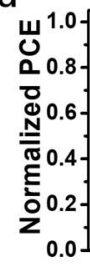

$\sim \mathrm{CsPbBr}_{3}+$ Filtered PBDB-T:ITIC

$\sim \mathrm{CsPBBr}_{3}+\mathrm{Filtered}$ PBDB-T-SF:IT-4F

$=-\mathrm{CsPbBr}_{3}+$ Filtered PTB7-Th:PC ${ }_{71}$ BM

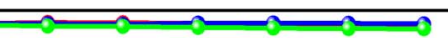

TSC

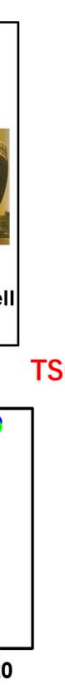

c

Colar spectrum
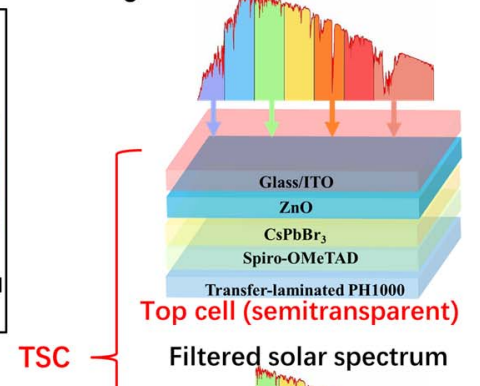

Filtered solar spectrum

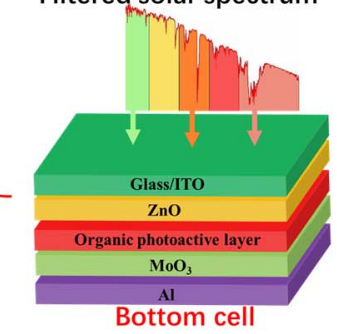

(a) $\mathrm{CsPbBr}_{3}$ 无机钻钦矿和以 PBDB-T:ITIC, PBDB-T-SF:IT-4F 或者 PTB7-Th:PC ${ }_{71} B M$ 为活性层的有机太阳电池的

外量子效率图; (b) $\mathrm{CsPbBr}_{3} / \mathrm{PBDB} \mathrm{T}-\mathrm{SF}: \mathrm{IT}-4 \mathrm{~F}$ 四电极叠层太阳电池 $J-V$ 曲线图, 插图为半透明 $\mathrm{CsPbBr}_{3}$ 钻钣矿 太阳电池透视图; (c)无机钻铁矿/有机四电极叠层太阳电池示意图; (d)无机钻钦矿/有机四电极叠层太阳电池 在紫外光照射下的电池效率随时间的变化图

近些年, 有机太阳电池得到快速发展, 但是在 商业化进程中仍然面临巨大挑战。其中，电池稳定 性问题(包括紫外光、水分、氧气等外界因素的影 响)一直是人们关注的焦点。虽然良好的电池封装 技术可以有效阻止水和氧气对有机太阳电池稳定 性的影响, 然而, 如何防止紫外光对有机共轭分子 结构和光伏器件稳定性的影响仍是一大难题。尽 管紫外光过滤薄膜可以有效过滤紫外光, 但同时
也会过滤部分可见光, 造成太阳电池性能的下降。

最近苏州大学李永舫研究团队的李耀文副教 授等人采用无机钙针矿/有机叠层太阳电池的策 略, 为提高电池的紫外光稳定性和电池效率提供 了一种新思路, 相关研究成果发表在近期的 Advanced Materials 上 ${ }^{1}$ 。他们通过真空蒸镀的方 法获得了宽带隙、低缺陷态的 $\mathrm{CsPbBr}_{3}$ 无机钙钛 矿薄膜, 基于此薄膜制备的平面型钻钣矿太阳电 
池可以充分利用紫外光(图 a), 获得了 $1.44 \mathrm{~V}$ 的超 高开路电压以及 $7.78 \%$ 的光电转换效率, 并表现出 了优异的紫外光稳定性(紫外光照射 $120 \mathrm{~h}$ 后性能 无衰减)。以 $\mathrm{CsPbBr}_{3}$ 薄膜为活性层制备的半透明 钙钛矿太阳电池(图 b)几乎可以完全过滤太阳光中 的紫外光, 并且在可见光区域(长于 $530 \mathrm{~nm}$ )的平 均透过率高达 $60 \%$ 。他们以该半透明钙钛矿太阳 电池为顶电池、以有机太阳电池为底电池制备了 四电极叠层太阳电池(图 c), 这种器件不仅可以有 效吸收和利用紫外光进行光电转换, 而且还避免 了紫外光对底部有机太阳电池的辐射, 获得了符 合工业应用标准的高紫外光稳定的叠层太阳电池
(图 d)。同时这种叠层太阳电池的最高光电转换效 率达到了 $14.03 \%$ (图 b), 是无机钻钛矿/有机叠层 太阳电池的最高效率。

该研究成果不仅解决了有机太阳电池所面临 的紫外光不稳定的瓶颈性问题, 同时也实现了光 电转换效率的提升，对于有机太阳电池的实际应 用具有重要意义。

\section{References}

(1) Chen, W.; Zhang, J.; Xu, G.; Xue, R.; Li, Y. W.; Zhou, Y.; Hou, J.; Li, Y. F. Adv. Mater. 2018, doi: 10.1002/adma.201800855 